\title{
Dapatkah Bersyukur Dan Kontrol Diri Mencegah Criminal Thinking Narapidana Kasus Kekerasan Seksual ?
}

\author{
Imaduddin Hamzah', Putri Rahmawaty Herlambang ${ }^{2}$ \\ 1Politeknik IImu Pemasyarakatan, 2Direktorat Jenderal Pemasyarakatan \\ email : imaduddin@poltekip.ac.id
}

\section{Artikel INFO}

Diterima:10 November 2020 Direvisi :09 Februari 2021 Disetujui: 04 Maret 2021

\section{DOI:}

http://dx.doi.org/10.24014/ jp.v14i2.11333

\begin{abstract}
Abstrak
Tujuan penelitian ini dalam menguji hubungan bersyukur, kontrol diri dengan criminal thinking dan peran kontrol diri sebagai mediator. Sejumlah kajian bersyukur secara mayotitas memfokuskan pada hubungannya dengan well-bering, kepuasan hidup dan perilaku prososial pada kelompok normal dan gangguan psikologis. Studi hubungan bersyukur dengan perilaku menyimpang masih sangat terbatas. Penelitian ini menggunakan analisis korelasional dan mediasi hubungan bersyukur, kontrol diri dan criminal thinking narapidana kasus kekerasan seksual. Pengukuran terhadap delapan puluh lima narapidana Lembaga Pemasyarakatan Kediri menggunakan skala gratitude, skala self-control Grasmick et.al. dan Psychological Inventory of Criminal Thinking Style (PICT). Hasil studi ini menemukan secara bersama-sama bersyukur dan self-control mempunyai relasi yang signifikan terhadap criminal thinking, namun kontrol diri menunjukkan peran inderect effect yang lemah sebagai mediator. Temuan ini berimplikasi pada pentingnya pengembangan program rehabilitasi pada aspek psikologis bersyukur dalam narapidana di lembaga pemasyarakatan.
\end{abstract}

Kata kunci : Gratitude; Kontrol diri; Criminal thinking

\section{Can Gratitude And Self-Control Prevent Criminal Thinking Of Sexual Offender Inmates?}

\begin{abstract}
The purpose of this study is to examine the relationship between gratitude, self-control, and criminal thinking. The majority of gratitude studies mostly focus on their relationship with well-being, life satisfaction, and prosocial behavior in normal and psychological disorders. Studies on the relationship between gratitude and deviant behavior are still very limited. This study uses correlational analysis and mediation of the relationship of gratitude, self-control, and criminal thinking of prisoners in sexual violence cases. The measurement of eighty-five prisoners in Kediri Penitentiary using the gratitude scale, Grasmick et al. 's self-control scale, and the Psychological Inventory of Criminal Thinking Style (PICT). The results of this study found that gratitude and self-control have a significant relationship with criminal thinking, but self-control shows a weak indirect effect role as a mediator. This finding has implications for the importance of developing a rehabilitation program on the psychological aspects of being grateful for inmates in prisons.
\end{abstract}

Keyowords : Gratitude; self-control; criminal thinking

\section{Pendahuluan}

Pemikiran kriminal (criminal thinking) merupakan aspek psikologis yang berperan penting dalam mengidentifikasi potensi pelaku kejahatan dan peluang pengulangan kejahatan di masa mendatang. Studi metaanalisis Walters (2012) menemukan criminal thinking mampu memprediksi residivisme (di luar kontribusi usia dan riwayat kriminal). Berdasarkan studi sebelumnya dengan metode yang sama mengungkapkan The Psychological Inventory of Criminal Thinking Styles (PICTS) berkorelasi dengan ukuran kriminalitas di masa lalu dan mampu memprediksi penyesuaiandiri setelah bebas di masa depan, meski pada tingkat yang rendah 
namun signifikan secara statistik (Walters, 2002). Namun, penelitian pemikiran kriminal di Indonesia tentang faktor-faktor yang dapat mempengaruhi pemikiran kriminal narapidana masih sangat terbatas dan hanya pada sampel peremuan. Penelitian kualitatif Brillianty dan Sugiaynto (2007) menemukan adanya efek konseling kognitif spiritual terhadap penurunan pola berpikir kriminal narapidana perempuan. Studi lainnya tentang pemikiran criminal terhadap 60 orang narapidana perempuan menunjukkan bahwa narapidana pelaku kejahatan pada jiwa mempunyai tingkat criminal thinking lebih tinggi dibanding dengan dua kejahatan yang lain (Sari \& Nuqul, 2014). Temuan-temuan tersebut menggambarkan masih minimnya kajian dan penjelasan teoritis tentang pemikiran kriminal dan faktor yang mempengaruhinya pada narapidana di Indonesia.

Narapidana yang telah melakukan kejahatan merupakan orang yang melakukan kejahatan dan memiliki mode pemikiran tertentu yang mendukung perilaku antisosial mereka. Penelitian Packer, Best, Day, dan Wood (2009) menemukan asosiasi yang kuat kontrol diri yang rendah dan criminal thinking yang tinggi. Menurut Taxman, Rhodes, dan Dumenci (2011) criminal thinking merupakan pola pikir terdistorsi yang mendukung rasionalisasi dan pembenaran perilaku kejahatan, terlibat gaya hidup kriminal dan menggunakan mode pemikiran yang mendukung perilaku anti-sosialnya. Criminal thinking didefinisikan sebagai isi dan proses pemikiran yang kondusif untuk menginisiasi dan memelihara kebiasaan perilaku melanggar hukum (Walters, 2006). Seseorang yang memiliki criminal thinking cenderung berfokus pada pikiran dan tindakan yang memperkuat pelanggaran hukum dan tindakan antisosial.

Studi ini mencoba menemukan peran bersyukur dan kontrol diri dalam mencegah criminal thinking. Bersyukur adalah salah satu sumber moral kebajikan. Bersyukur merupakan sebuah kebajikan, (perasaan dan emosi), yang berkaitan dengan tidak berperilaku jahat dan kebijaksanaan secara praktis (Chappell, 2019). Dalam penerapan sehari-hari, bersyukur sebagai moral kebaikan mempunyai fungsi sebagai barometer moral, motif moral dan penguat moral (McCullough et al., 2001).

Sejumlah penelitian psikologi mengidentifikasi dua jenis manfaat luas yang terkait dengan penanaman rasa syukur: manfaat bagi manfaat individu dan sosial (McConnell, 2016). Manfaat secara individual, studi menemukan keterkaitan bersyukur dengan psychologycal well being dan life satisfaction (Morgan, Gulliford, \& Kristjánsson, 2017; Sun \& Kong, 2013; Wood, Froh, \& Geraghty, 2010). Perasaan bersyukur juga memberikan efek psikologis meningkatkan kehidupan dan kesejahteraan individu dan pengembangan praktis dalam intervensi (Carr, 2016). Secara sosial, bersyukur berhubungan erat dengan menciptakan dan memelihara hubungan dan perilaku prososial (Algoe, Haidt, \& Gable, 2008; Bartlett, Condon, Cruz, Baumann, \& Desteno, 2012). Orang dengan bersyukur yang lebih tinggi membuat penilaian bermanfaat yang lebih positif (melihat bantuan lebih berharga, lebih mahal untuk disediakan, dan lebih banyak ditujukan sebagai pengorbanan), yang sepenuhnya memediasi hubungan antara sifat dan bentuk bersyukur (Wood, Maltby, Stewart, Linley, \& Joseph, 2008).

Bersyukur dikonseptualisasikan sebagai emosi, kebajikan, sentimen moral, motif, respons coping, keterampilan, dan sikap (Emmons \& Crumpler, 2000). Leung dan Tong (2017) menyatakan definisi bersyukur sebagai emosi positif yang dialami seseorang merespon suatu manfaat yang diterima dari sumber eksternal seperti orang lain atau faktor non-manusiawi (mis. cuaca yang baik, Tuhan). Studi ini mengartikan bersyukur sebagai, "perasaan berterima kasih, bahagia, serta apresiasi atas hal-hal yang diperoleh selama hidup, baik dari Tuhan, manusia, makhluk lain, dan alam semesta, yang kemudian mendorong seseorang untuk 
melakukan hal yang sama seperti yang ia dapatkan" (Listiyandini, Nathania, Syahniar, Sonia, \& Nadya, 2015). Tiga komponen gratutide dalam konsep ini meliputi, 1) memiliki rasa apresiasi terhadap orang lain, Tuhan dan kehidupan, 2) merasaan positif terhadap kehidupan yang dimiliki, dan 3) kecenderungan untuk bertindak positif sebagai ekspresi dari perasaan positif dan apresiasi yang dipunyai (Fitzgerald, 1998; Listiyandini et al., 2015).

Studi ini mendasarkan pada pemikiran bahwa bersyukur sebagai penguat moral dan perilaku prososial, sehingga seseorang dapat mengendalikan diri melakukan tindakan yang merugikan orang lain. McCullough, Emmons, Kilpatrick, \& Larson, (2001) berpandangan menyatakan bersyukur merupakan moral affect yang analog dengan emosi moral lainnya seperti empati dan rasa bersalah, respon terhadap kebaikan dan manfaat kepada orang lain (Roberts \& Telech, 2019). Penelitian Bartlett et al., (2012) menunjukkan dampak bersyukur terhadap perilaku baik secara sosial. Mereka menemukan bahwa bersyukur meningkatkan afiliasi sosial dan memperkuat hubungan dengan fasilitasi perilaku inklusif sosial. Sehingga seseorang yang bersyukur dapat mengarahkan diri pada perilaku yang lebih bermanfaat untuk orang lain dan mengendalikan diri dari perbuatan yang merugikan orang lain (antisosial), seperti tindakan kekerasan seksual.

Ungkapan rasa syukur dapat meningkatkan ekspresi yang menguatkan relasi komunal dan interaksi positif dengan orang lain (Lambert, Clark, Durtschi, Fincham, \& Graham, 2010). Sementara para pelaku kejahatan kekerasan seksual dicirikan sebagai orang yang memiliki kesulitan berhubungan secara efektif dengan orang dewasa (Marshall, 1999). Seseorang yang melakukan kejahatan seksual memperlihatkan masalah dalam perilaku sosial. Mereka melanggar larangan sosial yang kuat dan tidak mampu mengendalikan diri mendapatkan kepuasan seksual dengan menyakiti orang lain. Pelaku kekerasan seksual juga memiliki defisit keintiman, proses pemikiran yang menyimpang, deregulasi emosional, kognisi antisosial yang melibatkan dan kurang memperhatikan kebutuhan emosional dan psikologis orang lain (Faupel, 2015). Berdasarkan penjelasan tersebut, studi ini mengajukan hipotesis bahwa rasa bersyukur mampu menekan criminal thinking untuk menyakiti orang lain, seperti kasus kekerasan seksual.

Bersukur menjadikan seseorang dapat lebih mengendalikan dirinya. Studi (Wood, Joseph, \& Linley, 2007) menemukan bahwa syukur berkorelasi negatif dengan perilaku tidak terkendali, menyalahkan diri sendiri, penggunaan narkoba, dan penyangkalan. Ungkapan bersyukur pada individu dengan maladaptif yang rendah berasosiasi dengan kontrol diri yang tinggi (O'Keefe, 2017). Dalam temuan studi DeSteno, Duong, Lim, \& Kates (2019) menyatakan bahwa rasa syukur juga dapat meningkatkan kontrol diri dan membuat mereka cenderung tidak menyerah pada godaan untuk menipu.

Menurut Self control theory (Gottfredson dan Hirschi, 1990), para pelaku kejahatan memiliki kontrol diri yang rendah, yakni kurang memiliki kemampuan menolak godaan dan menunda pemuasan (Cleary, 2004). Kontrol diri rendah diklaim berkaitan dengan kecenderungan untuk mencari kesenangan jangka pendek dan cepat, yang dan mempunyai korelasi intrapersonal penting dengan kejahatan dan kenakalan (Wiebe, 2006). Seseorang dengan kontrol diri rendah menunjukkan ciri impulsivitas, preferensi untuk hal yang sederhana daripada kompleks, mencari resiko, preferensi pada aktivitas fisik daripada otak, orientasi pada diri sendiri. (Grasmick, Tittle, Bursik, \& Arneklev, 1993). 
Studi meta-analisis terbaru tentang perilaku dan sikap kontrol diri rendah menemukan bahwa tindakan dan sikap kontrol diri rendah berkorelasi sama tingginya dengan tindakan kriminalitas dan kenakalan (Walters, 2016a). Kontrol diri yang rendah menimbulkan kenakalan melalui proses pengekangan perilaku yang lemah, dan pengekangan perilaku yang lemah dapat menyebabkan pengekangan kognitif yang lemah atau yang dikenal dalam teori gaya hidup sebagai criminal thinking yang reaktif (Walters, 2016b). Studi Walters (2017b) menemukan bahwa criminal thinking reaktif merupakan konsekuensi dari kontrol diri yang rendah (kontrol diri secara signifikan menjadi prediktor criminal thinking).

Gottfredson dan Hirschi (1990) menyatakan bahwa pelaku pelanggaran secara fundamental tidak dapat menahan godaan atau menunda kepuasan dalam menghadapi peluang -ini merupakan inti dari pengendalian diri yang rendah. Hasil penelitian berdasarkan pandangan Gottfredson dan Hirschi menemukan pelaku kekerasan seksual sebagai individu yang picik, impulsif, tidak sensitif yang tidak dapat menunda kepuasan dan tidak dapat menahan diri ketika dihadapkan dengan godaan (Cleary, 2004). Pelaku juga menunjukkan ciri problem dalam perilaku sosial yang menunjukkan negative social influences dan kesendirian (Mann, Hanson, \& Thornton, 2010). Dari berbagai penjelasan tentang kontrol diri tersebut, studi ini mengajukan hipotesis bahwa kontrol diri yang kuat berhubungan dengan criminal thinking yang rendah, serta dapat memediasi efek bersyukur dengan criminal thinking Bersyukur mendorong kebajikan, perilaku prososial dan sebagai moral emosi yang dapat mengendalikan pemikiran, motivasi jahat dan antisosial.

\section{Metode}

\section{Partisipan}

Penelitian dilakukan terhadap delapan puluh lima partisipan (laki-laki, usia 18-64 tahun) berstatus narapidana kasus kekerasan seksual pada Lembaga Pemasyarakatan Klas. II A Kota kediri, Provinsi Jawa Timur, Indonesia. Jumlah narapidana kasus kekerasan seksual adalah 100 orang, namun lima belas narapidana tidak dapat mengisi kuesioner karena kelemahan pada mata (penglihatan) dan kemampuan membaca. Narapidana yang mengikuti penelitian ini telah menyatakan persetujuan secara tertulis untuk terlibat sebagai partisipan. Penelitian ini telah memperoleh izin dan persetujuan resmi dari Kantor Kementerian Hukum dan Hak Asasi Manusia, Provinsi Jawa Timur dan Kepala Lembaga Pemasyarakatan Klas II A Kediri.

\section{Pengukuran}

Pengukuran bersyukur menggunakan skala bersyukur dengan versi Indonesia, dikembangkan oleh Listiyandini et al. (2015). Skala terdiri dari 30 item (12 item favorable, 18 item unfavorable) dengan pilihan respon skala likert 1 - 6 (1 = sangat tidak sesuai, 6 = sangat sesuai). Reliabilitas alpha-cronbach skala ini sebesar $\alpha=0.932$ dan validitas item $r$ $=0.3$ - 0.6 pada kelompok normal. Reliabilitas pada kelompok narapidana $\alpha=0.70$, validitas item $(r=0.257-0.512)$.

Konstruk bersyukur berisi tiga faktor dengan jenis transpersonal dan personal. Pertama sense of appreciation (perasaan menghargai), dengan indikator menyadari kesenangan sederhana (simple pleasure) yang diperoleh dari Tuhan dan kehidupan dan mengakui peran orang lain untuk kesejahteraan kita. Contoh item faktor ini, "kesehatan yang saya milikiberasaldari Tuhan, ketika memandang wajah anggota keluarga, saya menyadari betapa berharganya memiliki 
mereka". Faktor kedua adalah perasaan positif akan kehidupan. Indikatornya antara lain merasa puas dengan hidupnya dan merasa bahagia karena keberadaan orang lain. Contoh item faktor ini "saya merasa sudah memiliki segala hal positif dalam hidup, saya kesepian walaupun dikelilingi oleh teman-teman saya (unfavorable)". Faktor bersyukur yang ketiga adalah ekspresi rasa syukur dengan indikator diantaranya menjalani aktivitas sebaik mungkin sebagai bentuk terima kasih kepada hidup dan Tuhan dan membalas kebaikan orang lain sebagai wujud apresiasi. Contoh pernyataan pada faktor ketiga ini, "ketika saya menerima suatu karunia, saya langsung mengucapkan pujian kepada Tuhan, Karena saya merasa hidup berkecukupan, saya patut membantu orang lain yang kurang mampu.".

Penelitian ini menggunakan skala selfcontrol yang disusun oleh Grasmick et al., (1993). Skala terdiri dari 24 pernyataan dengan empat respon dari $1=$ strongly disagree, ke $4=$ strongly agree. Skala ini mampu mengidentifikasi hubungan positif untuk mengukur perilaku menyimpang, dengan komponen meliputi: impulsivity, simple task, risk seeking, physical activities, self-centered dan temper (Cretacci, Ding, \& Rivera, 2010; Grasmick et al., 1993; Vazsonyi, Mikuška, \& Kelley, 2017),. Skala ini memiliki relibilitas alpha-cronbach $\alpha=0.824$ dan validitas item sebesar $r=0.382-0.722$. Beberapa pernyataan dalam skala kontrol diri, seperti "kadang-kadang saya merasa senang melakukan hal-hal yang mungkin membuat saya mendapatkan masalah, Saya sering bertindak secara mendadak tanpa berhenti untuk berpikir."

Criminal thinking diukur dengan Psychological Inventory of Criminal Thinking Styles PICT) yang memiliki 37 item meliputi 6 subscale : entitlement, justification, personal irresponsibility, power orientation, cold heartedness, and criminal rationalization (Knight, Garner, Simpson, Morey, \& Flynn,
2006; Taxman et al., 2011; Walters, 1995). Penskoran jawaban menggunakan 4-point Likert-type scale $(1=$ disagree strongly, $2=$ disagree, $3==$ agree, $4=$ agree strongly). Relibilitas alpha-cronbach $\alpha=0.765$, dan nilai validitas item $r=0.218-0.708$ (kelompok narapidana). Ini contoh pernyataan yang mengukur pemikiran kriminal, seperti "saya melakukan tindak kejahatan, karena lingkungan yang membuat saya melakukannya, polisi lebih banyak melakukan pelanggaran disbanding dengan penjahat yang mereka tangkap."

\section{Analisis data}

Analisis mediasi statistik digunakan untuk menguji hipotesis tentang proses di mana satu variabel $X$ mentransmisikan efeknya pada variabel $Y$ lainnya melalui satu atau lebih variabel mediator atau variabel $M$ (Hayes \& Rockwood, 2017; Rockwood \& Hayes, 2020). Analisis mediasi menggunakan JASP 0.10.2.0 dengan bersyukur sebagai prediktor $(X)$, criminal thinking $(Y)$ sebagai variabel outcome dan varibel mediasi (M) adalah kontrol diri. Analisis korelasi dilakukan untuk menguji hubungan antar setiap komponen pada masing-masing variabel bersyukur dan criminal thinking.

\section{Hasil}

Tabel 1 mendeskripsikan demografi partisipan tentang pendidikan, usia dan status pernikahan sebelum partisipan dimasukkan ke institusi pemasyarakatan. Aspek pendidikan partisipan menunjukkan sebagian besar sekolah menengah $70,58 \%$ (sekolah menengah). Usia partisipan dengan jumlah terbanyak 20-34 tahun (58.82\%). Yang menarik, jumlah partisipan pelaku kejahatan kekerasan seksual masih dalam status menikah lebih tinggi dari yang telah bercerai atau berpisah dari pasangan (tabel 1). 
Table 1 . Demografi partisipan

\begin{tabular}{llrr}
\hline & & $n$ & $\%$ \\
\hline Pendidikan & SD & 21 & 24.71 \\
& SMP & 30 & 35.29 \\
& SMA sederajat & 30 & 35.29 \\
& Perguruan tinggi & 4 & 4.71 \\
\hline \multirow{3}{*}{ Usia } & $<20$ & 2 & 2.35 \\
& $20-34$ & 50 & 58.82 \\
& $35-49$ & 22 & 25.88 \\
Status Pernikahan & Menikah & 11 & 12.94 \\
& Belum menikah/ Sendiri & 39 & 45.88 \\
& Bercerai & 36 & 42.35 \\
& & 9 & 10.59 \\
\hline
\end{tabular}

Note. SD = Sekolah Dasar, SMP = Sekolah menengah Pertama,

SMA $=$ Sekolah Menengah Atas

Hasil uji hipotesis pertama menemukan direct effect bersyukur dan criminal thinking secara signifikan $(p=0.015<0.05, \mathrm{Cl}=-0.297$,0.032). Jika dilihat secara lebih rinci melalui scatter plot pada gambar 1 , menggambarkan bahwa meningginya bersyukur, diikuti dengan criminal thinking yang merendah. Temuan ini membuktikan hipotesis bahwa bersyukur berpengaruh secara negatif terhadap criminal thinking.

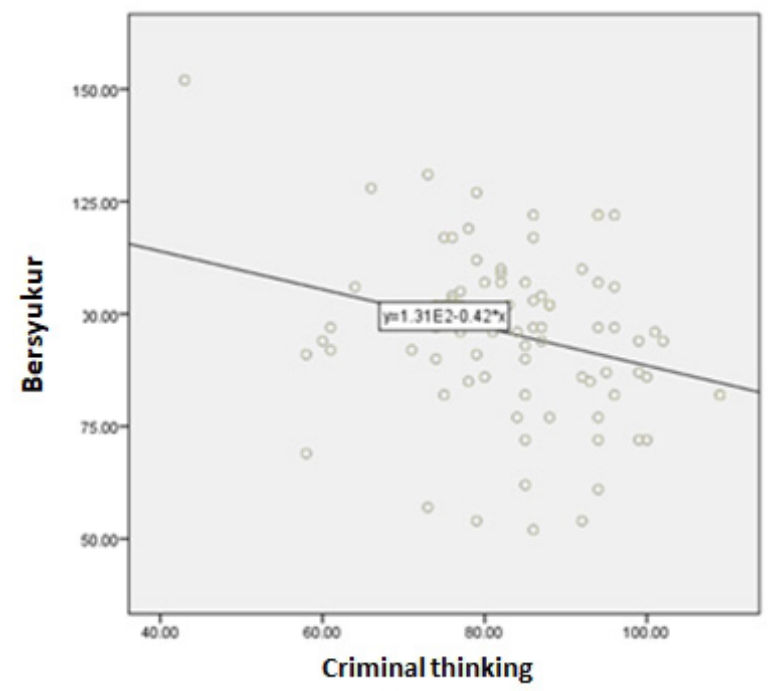

Gambar 1. Scatter Plot Bersyukur Dan Criminal Thinking

Bersyukur dan kontrol diri menunjukkan korelasi yang tidak signifikan $(p=0.17<0.05$, $\mathrm{Cl}=-0.3351,-0.065)$. Hubungan kontrol diri dengan criminal thinking menunjukkan korelasi yang lemah $(p=0.10<0.05, \mathrm{Cl}=$ $-0.035,-0.377)$. Berdasarkan analisis mediasi bersyukur $\rightarrow$ kontrol diri $\rightarrow$ criminal thinking menyimpulkan tidak adanya indirect effect melalui mediator kontrol diri $(p=0.33>0.05)$, namun total effect menunjukkan adanya efek yang signifikan $(p=0.008<0.05, \mathrm{Cl}$ $=-0.310,-0.046)$ (lihat gambar 2). Hasil ini menggambarkan bahwa secara bersamasama bersyukur dan kontrol diri mempunyai pengaruh yang signifikan terhadap criminal thinking. 


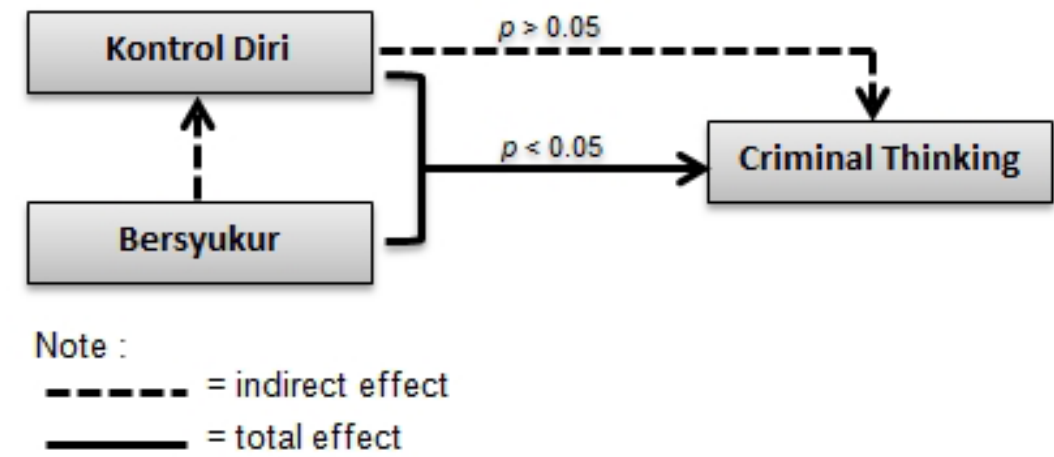

Gambar 2. Bersyukur dan criminal thinking dengan mediasi kontrol diri

Analisis korelasi pada setiap komponen variabel bersyukur dan criminal thinking (tabel 2) menemukan kontribusi signifikan dua dari tiga komponen bersyukur berhubungan dengan criminal thinking, yaitu self of appreciation $(-.266, p<0.05)$ dan positive affection $(-.234, p<0.05)$. Sementara hubungan komponen gratitude expressioncriminal thinking tidak menunjukkan asosiasi yang signifikan $(-.148, p>0.05)$.

Table 2. Korelasi Komponen Bersyukur Dan Criminal Thinking

\begin{tabular}{llccccccccc}
\hline & & 1 & 2 & 3 & 4 & 5 & 6 & 7 & 8 & 9 \\
\hline 1 & $\mathrm{SA}$ & - & & & & & & & & - \\
2 & $\mathrm{PA}$ & $.438^{* *}$ & - & & & & & & \\
3 & $\mathrm{GE}$ & $.569^{* *}$ & $.367^{* *}$ & - & & & & & \\
4 & $\mathrm{ENT}$ & $-.344^{* *}$ & $-.291^{* *}$ & -0.202 & - & & & & \\
5 & $\mathrm{JF}$ & -0.107 & -0.082 & -0.034 & $.560^{* *}$ & - & & & \\
6 & $\mathrm{PO}$ & -0.135 & -0.136 & -0.169 & $.551^{* *}$ & $.531^{* *}$ & - & & \\
7 & $\mathrm{CH}$ & -0.074 & -0.017 & 0.021 & 0.077 & $.333^{* *}$ & 0.130 & - & & \\
8 & $\mathrm{CR}$ & -0.175 & $-.237^{*}$ & -0.070 & $.424^{* *}$ & $.556^{* *}$ & $.376^{* *}$ & $.485^{* *}$ & - & \\
9 & $\mathrm{PI}$ & $-.303^{* *}$ & $-.220^{*}$ & -0.137 & $.542^{* *}$ & $.443^{* *}$ & $.434^{* *}$ & $.234^{*}$ & $.491^{* *}$ & - \\
\hline
\end{tabular}

Note. $\mathrm{SA}=$ sense of appreciation; $\mathrm{PA}=$ positive affection; $\mathrm{GE}=$ gratitude expression; ENT = entitlement; JF = justification; $\mathrm{PO}=$ power orientation; $\mathrm{CH}=$ cold heartedness; $\mathrm{CR}=$ criminal rationalization; $\mathrm{PI}=$ personal irresponsibility; ${ }^{*} \mathrm{p}<.05 ;{ }^{* *} \mathrm{p}<.01$;

\section{Pembahasan}

Temuan penelitian ini membuktikan hipotesis pertama yang menyatakan relasi bersyukur dengan criminal thinking. Tingkat bersyukur yang tinggi berhubungan secara signifikan dengan criminal thinking yang rendah para narapidana kasus kekerasan seksual. Temuan ini mendukung teori yang dijelaskan sebelumnya bahwa bersyukur mempunyai hubungan dengan perilaku prososial dan moral kebajikan (Bartlett \& DeSteno, 2006; McCullough, Emmons, \& Tsang, 2002; Morgan et al., 2017). Kesimpulan studi ini juga memperluas temuan studi bersyukur. Bersyukur tidak hanya memiliki hubungan positif bersyukur dengan wellbeing, life-satisfaction dan prososial, tetapi juga berkorelasi negatif dengan rendahnya criminal thinking pada pelaku kejahatan kekerasan seksual. 
Para pelaku kekerasan seksual mempunyai karakteristik umum perilaku interpersonal maladaptif, impulsif, dan antisosial (McMunn, 2019), agresif, novelty seeking, kurang empatik, dan pengarahan diri yang rendah (Giotakos, Vaidakis, Markianos, \& Christodoulou, 2003). Analisis relasi pada studi ini mengidentifikasi sense of appreciation dan positive affection sebagai komponen bersyukur yang paling berasosiasi dengan rendahnya criminal thinking para pelaku kejahatan kekerasan seksual. Narapidana pelaku kejahatan pada jiwa mempunyai memiliki tingkat criminal thinking lebih tinggi dibanding dengan kejahatan properti dan narkoba (Sari \& Nuqul, 2014). Seseorang yang bersyukur memiliki sense of appreciation tinggi dapat menunjukkan perasaan menghargai orang lain, Tuhan, kesenangan yang sederhana, dan kerendahan hati (Listiyandini et al., 2015). Sementara pelaku kejahatan kekerasan seksual mempunyai perasaan yang tidak aman, kemarahan dan kecemasan umum yang lebih tinggi daripada non kejahatan seksual (Lyn \& Burton, 2005).

Penjelasan ini memperkuat dengan kesimpulan penelitian sebelumnya yang menerangkan bahwa bersyukur meningkatkan perbuatan baik yang terkait dengan kemampuan untuk menolak godaan (DeSteno et al., 2019), menerima diri dan menjalin hubungan yang positif dengan orang lain. (Wood, Joseph, \& Maltby, 2009). Bersyukur juga mampu menghambat entitlement, rasa berlebihan mementingkan diri sendiri dan tidak sensitif terhadap orang lain (Peterson \& Seligman, 2004). Sementara menurut Quadripartite Model pelaku kejahatan seksual mengalami distorsi berpikir dengan membenarkan kekerasan seksual yang dilakukan dan mempunyai keyakinan mendapatkan manfaat (kenikmatan) lebih besar dari agresi seksual daripada risiko hukuman (Mann et al., 2010). Dengan demikian, studi ini menyimpulkan bahwa besyukur dapat berperan untuk mencegah criminal thinking.
Uji hipotesis studi ini juga menemukan meski ditemukan korelasi kontrol diri dengan criminal tihinking, namun nampak lemah. Kontrold iri juga tidak berperan menjadi mediator bersyukur dengan criminal-thinking. Namun kontrol diri dan bersyukur secara bersama-sama memberikan efek langsung yangkuatterhadapcriminalthinking.Penolakan hipotesis ini berbeda dengan temuan Packer et al. (2009) yang mengungkapkan adanya asosiasi kontrol diri dan pemikiran kriminal pada penggunaan narkoba dan pelanggaran. Packer et al. menjelaskan adanya hubungan kontrol diri dengan criminal thinking dikaitkan dengan usia yang lebih muda, dan adanya bukti hubungan antara usia yang lebih muda dan pemikiran kriminal yang lebih tinggi. Penjelasan ini didukung oleh studi Engel (2012) yang menyimpulkan adanya diferensiasi pada signifikansi kontrol diri rendah dengan kejahatan berdasarkan usia pelaku dan jenis pelanggaran/ kejahatan. Dengan demikian, temuan studi ini menemukan adanya perbedaan dengan teori sebelumnya yang dikemukakan Walters (2017) bahwa rendahnya perilaku kontrol diri ini mempunyai korelasi yang lebih signifikan terhadap perilaku anti-sosial dan menjadi sumber criminal thinking. Hubungan kontrold diri-criminal thinking tersebut ternyata tidak ditemukan pada jenis kejahatan seksual dan pelaku kejahatan yang telah berusia dewasa.

Bersyukur secara bersama-sama dengan kontrol diri mempunyai relasi signifikan dengan criminal thinking. Bersukur yang tinggi didukung dengan kontrol diri yang tinggi menjadi sumber moral kebajikan yang dapat mencegah munculnya criminal thinking. Bersyukur menunjukkan manfaat secara sosial, sebagai faktor penentu tindakan pelanggaran atau kejahatan. Dari penjelasan ini, program rehabilitasi narapidana kasus kekerasan memerlukan intervensi penguatan bersyukur dan kontrol diri selama melaksanakan hukuman di lembaga pemasyarakatan. 
Keterbatasan yang teridientifikasi dalam studi ini dengan jumlah partisipan. Populasi narapidana kasus kejahatan kekerasan seksual tergolong kecil pada lembaga pemasyarakatan dan sebagian pelaku berpendidikan sekolah dasar, sehingga kurang dapat membaca dan menulis dengan lancar. Berbeda dengan dengan populasi narapidana kasus narkoba dan pencurian (dengan atau tanpa kekerasan) yang mendominasi lapas di Indonesia. Berdasarkan temuan penelitian, disarankan studi lebih lanjut dilakukan jumlah partisipan yang lebih besar. Adanya hubungan kontrol diri dengan criminal thinking dengan taraf signifikansi yang rendah, maka penelitian di masa datang juga perlu mempertimbangkan menggunakan populasi narapidana dengan jenis pidana yang beragam, serta menggunakan instrumen kontrol diri yang lebih spesifik seperti kontrol hasrat atau perilaku seksual.

\section{Kesimpulan}

Hasil penelitian ini memperluas teori yang ada bahwa manfaat bersyukur bukan hanya secara individual (well being, self satisfaction) dan prososial, tetapi juga mempunyai efek langsung untuk mencegah munculnya criminal thinking. Konsep bersyukur dalam penelitian tidak terbatas pada personal dan relasi interpersonal, melainkan menunjukkan adanya faktor keyakinan terhadap Tuhan dalam bersyukur. Hasil penelitian ini dapat menjadi rekomendasi untuk program rehabilitasi terhadap pembinaan narapidana di lembaga pemasyarakatan konseling keagamaan, seperti pengembangan rasa bersyukur.

\section{Daftar Pustaka}

Algoe, S. B., Haidt, J., \& Gable, S. L. (2008). Beyond Reciprocity: Gratitude and relationships in everyday life. Emotion, 8(3), 425-429. https://doi. org/10.1037/1528-3542.8.3.425.
Bartlett, M. Y., Condon, P., Cruz, J., Baumann, J., \& Desteno, D. (2012). Gratitude: Prompting behaviours that build relationships. Cognition and Emotion, 26(1), 2-13. https://doi.org/10.1080/026 99931.2011 .561297

Bartlett, M. Y., \& DeSteno, D. (2006). Gratitude and prosocial behavior: Helping when it costs you. Psychological Science, 17(4), 319-325. https://doi.org/10.1111/j.14679280.2006.01705.x

Carr, D. (2016). Perspectives on Gratitude: An Interdisciplinary Approach. In D. Carr (Ed.), Perspectives on Gratitude. New York: Routledge.

Chappell, S. G. (2019). Gratitude as a Virtue. In R. Roberts \& D. Telech (Eds.), The Moral Psychology of Gratitude. London: Rowman \& Littlefield International Ltd.

Cleary, S. (2004). Sex offenders and selfcontrol: Explaining sexual violence. In Knowledge Creation Diffusion Utilization. New York: LFB Scholarly Publishing LLC. Cretacci, M., Ding, F. M., \& Rivera, C. (2010). Traditional and Bond Measures of SelfControl and Their Impact on Deviance among Chinese University Students. International Journal of Criminal Justice Sciences, 5(1), 220-238.

DeSteno, D., Duong, F., Lim, D., \& Kates, S. (2019). The Grateful don'tcheat: Gratitude as a fount of virtue. Psychological Science, 30(7), 979-988. https://doi. org/10.1177/0956797619848351

Emmons, R. A., \& Crumpler, C. A. (2000). Gratitude as a human strength: Appraising the evidence. Journal of Social and Clinical Psychology, 19(1), 56-69. https://doi.org/10.1521/ jscp.2000.19.1.56

Engel, C. (2012). Low self-control as a source of crime: A meta-study. Retrieved from http://homepage.coll.mpg.de/pdf dat/2012_04online.pdf

Faupel, S. (2015). Etiology of adult sexual offending. Retrieved from https://www.smart.gov/pdfs/ EtiologyofAdultSexualOffending.pdf 
Fitzgerald, P. (1998). Gratitude and justice. Ethics, 109(1), 119-153. https://doi. org/10.1086/233876

Giotakos, O., Vaidakis, N., Markianos, M., \& Christodoulou, G. N. (2003). Personality characteristics of sexual offenders. Psychiatriki, 14(3), 189-190. Retrieved from https://psycnet.apa.org/ record/2004-10411-001

Gottfredson, M. R., \& Hirschi, T. (1990). A General Theory of Crime. Stanford: Stanford University Press.

Grasmick, H. G., Tittle, C. R., Bursik, R. J., \& Arneklev, B. J. (1993). Testing the core empirical implications of Gottfredson and Hirschi's general theory of crime. Journal of Research in Crime and Delinquency, 30(1), 5-29. https://doi. org/10.1177/0022427893030001002

Hayes, A. F., \& Rockwood, N. J. (2017). Regression-based statistical mediation and moderation analysis in clinical research: Observations, recommendations, and implementation. Behaviour Research and Therapy, 98, 39-57. https://doi.org/10.1016/j. brat.2016.11.001

Knight, K., Garner, B. R., Simpson, D. D., Morey, J. T., \& Flynn, P. M. (2006). An assessment for criminal thinking. Crime and Delinquency, 52(1), 159-177. https:// doi.org/10.1177/0011128705281749

Lambert, N. M., Clark, M. S., Durtschi, J., Fincham, F. D., \& Graham, S. M. (2010). Benefits of expressing gratitude: Expressing gratitude to a partner changes one' $s$ view of the relationship. Psychological Science, 21(4), 574-580. https://doi. org/10.1177/0956797610364003

Leung, C. C., \& Tong, E. M. W. (2017). Gratitude and drug misuse: Role of coping as mediator. Substance Use and Misuse, 52(14), 1832-1839. https://doi. org/10.1080/10826084.2017.1312449

Listiyandini, R. A., Nathania, A., Syahniar, D., Sonia, L., \& Nadya, R. (2015). Measuring gratitude: Early model development of the grateful scale Indonesian version. Jurnal Psikologi Ulayat, 2(2), 473-496. https://doi.org/10.24854/jpu22015-41

Lyn, T. S., \& Burton, D. L. (2005). Attachment, anger and anxiety of male sexual offenders. Journal of Sexual Aggression, 11(2), 127-137. https://doi. org/10.1080/13552600500063682

Mann, R. E., Hanson, R. K., \& Thornton, D. (2010). Assessing risk for sexual recidivism : Some proposals on the nature of psychologically meaningful risk factors. Sexual Abuse, 22(2), 191-217. https:// doi.org/10.1177/1079063210366039

Marshall, W. L. (1999). Current status of North American assessment and treatment programs for sexual offenders. Journal of Interpersonal Violence, 14(3), 221-239. https://doi. org/10.1177/088626099014003002

McConnell, T. (2016). Gratitude's Value. In D. Carr (Ed.), Perspectives on Gratitude: An Interdisciplinary Approach (pp. 1326). New York: Routledge.

McCullough, M. E., Emmons, R. A., Kilpatrick, S. D., \& Larson, D. B. (2001). Is Gratitude a Moral Affect? Psychological Bulletin, 127(2), 249-266. https://doi. org/10.1037/0033-2909.127.2.249

McCullough, M. E., Emmons, R. A., \& Tsang, J. A. (2002). The grateful disposition: A conceptual and empirical topography. Journal of Personality and Social Psychology, 82(1), 112-127. https://doi. org/10.1037/0022-3514.82.1.112

McMunn, P. E. (2019). Psychological Characteristics of Sex Offenders (Walden University). Retrieved from https://scholarworks.waldenu.edu/cgi/ viewcontent.cgi?article $=7898 \&$ context $=$ dissertations

Morgan, B., Gulliford, L., \& Kristjánsson, K. (2017). A new approach to measuring moral virtues: The multi-component gratitude measure. Personality and Individual Differences, 107, 179-189. https://doi.org/10.1016/j. 
paid.2016.11.044

O'Keefe, S. D. (2017). Willingness to Express Gratitude: The Role of SelfRegulation and Self Focus (University of Rochester). Retrieved from http://hdl. handle.net/1802/32734

Packer, G., Best, D., Day, E., \& Wood, K. (2009). Criminal thinking and self-control among drug users in court mandated treatment. Criminology and Criminal Justice, 9(1), 93-110. https://doi. org/10.1177/1748895808099182

Peterson, C., \& Seligman, M. E. P. (2004). Character Strengths and Virtues. Oxford: Oxford University Press.

Roberts, R., \& Telech, D. (2019). The Emotion-Virtue-Debt Triad of Gratitude: An Introduction to The Moral Psychology of Gratitude. In R. Roberts \& D. Telech (Eds.), The Moral Psychology of Gratitude. London: Rowman \& Littlefield International Ltd.

Rockwood, N. J., \& Hayes, A. F. (2020). Mediation, Moderation, and Conditional Process Analysis. In The Cambridge HandbookofResearchMethods in Clinical Psychology (pp. 396-414). https://doi. org/10.1017/9781316995808.037

Sari, I. N., \& Nuqul, F. L. (2014). Criminal thinking pada narapidana wanita. Retrieved from http://repository.uinmalang.ac.id/818/1/Criminal Thinking Ika Novita Sari _ Fathul Lubabin Nuqul. pdf

Sun, P., \& Kong, F. (2013). Affective mediators of the influence of gratitude on Life satisfaction in late adolescence. Social Indicators Research, 114(3), 13611369. https://doi.org/10.1007/s11205013-0333-8

Taxman, F. S., Rhodes, A. G., \& Dumenci, L. (2011). Construct and predictive validity of criminal thinking scales. Criminal Justice and Behavior, 38(2), 174-187. https:// doi.org/10.1177/0093854810389550

Vazsonyi, A. T., Mikuška, J., \& Kelley, E. L. (2017). It's time: A meta-analysis on the self-control-deviance link. Journal of
Criminal Justice, 48, 48-63. https://doi. org/10.1016/j.jcrimjus.2016.10.001

Walters, G. D. (1995). The psychological inventory of criminal thinking styles: Part I: Reliability and Preliminary Validity. Criminal Justice and Behavior, 22(3), 307-325. https://doi. org/10.1177/0093854895022003008

Walters, G. D. (2006). Appraising, researching and conceptualizing criminal thinking: $A$ personal view. Criminal Behaviour and Me, 16, 87-99. https://doi.org/10.1002/ $\mathrm{cbm} / \mathrm{cbm} .50$

Walters, G. D. (2016a). Are behavioral measures of self-control and the grasmick self-control scale measuring the same construct? A meta-analysis. American Journal of Criminal Justice, 41(2), 151-167. https://doi.org/10.1007/ s12103-015-9317-3

Walters, G. D. (2016b). Low self-control, peer rejection, reactive criminal thinking, and delinquent peer associations: connecting the pieces of the crime puzzle. Journal of Developmental and Life-Course Criminology, 2(2), 209-231. https://doi. org/10.1007/s40865-016-0028-3

Walters, G. D. (2017a). Measuring low selfcontrol and reactive criminal thinking in the NLSY-child sample: One construct or two? American Journal of Criminal Justice, 42(2), 314-328. https://doi. org/10.1007/s12103-016-9365-3

Walters, G. D. (2017b). Reactive criminal thinking as a consequence of low selfcontrol and prior offending. Deviant Behavior, 38(2), 1-11. https://doi.org/10 .1080/01639625.2016.1196951

Wiebe, R. P. (2006). Using an expanded measure of self-control to predict delinquency. Psychology, Crime and Law, 12(5), 519-536. https://doi. org/10.1080/10683160500254953

Wood, A. M., Froh, J. J., \& Geraghty, A. W. A. (2010). Gratitude and well-being: $A$ review and theoretical integration. Clinical Psychology Review, 30(7), 
890-905. https://doi.org/10.1016/j. cpr.2010.03.005

Wood, A. M., Joseph, S., \& Linley, A. A. (2007). Coping style as a psychological resource of grateful people. Journal of Social and Clinical Psychology, 26(9), 1076-1093. https://doi.org/10.1521/ jscp.2007.26.9.1076

Wood, A. M., Joseph, S., \& Maltby, J. (2009). Gratitude predicts psychological wellbeing above the Big Five facets. Personality and Individual Differences, 46(4), 443-447. https://doi.org/10.1016/j. paid.2008.11.012

Wood, A. M., Maltby, J., Stewart, N., Linley, P. A., \& Joseph, S. (2008). A SocialCognitive Model of trait and state levels of gratitude. Emotion, 8(2), 281-290. https://doi.org/10.1037/15283542.8.2.281 